\title{
5
}

\section{An uneasy alliance}

Despite the lamentations of seventeenth-century reformers about the inadequacies of religious belief and practice among the French population, they at least had the satisfaction of knowing that there was no real danger that protestantism would ever again challenge the privileged position of the Catholic church. Catholicism was the religion of France, of the majority of French people and of the royal family. Its clergy composed the first estate and were represented at provincial and national estates; they even had their own official Assembly in which their mainly episcopal deputies could voice the church's concerns and seek support from the crown. With privileges came responsibilities, however, for just as the church made demands on the temporal realm so it sought to gain from its connections with the church. As the self-proclaimed leaders of the French church, the bishops were at the centre of this far from straightforward exchange.

The topic of church-state relations is a vast one, only aspects of which relate directly to the episcopate and episcopal ideology. What follows is not a full-scale analysis of church-state relations per se, since this would merit an entire book of its own. ${ }^{1}$ Yet, having explored the episcopate's vision of its hierarchical role within the church, we must turn to its relationship with that other great institution, the French monarchical realm. It is clear that many bishops had an ambivalent attitude towards the temporal government for, despite realising the immense benefits that it could and did bring to them and to their church, they proved acutely suspicious of its tendencies to undermine their jurisdictional liberty and dignity. They fought a running battle throughout the century to ensure that these principles would be safeguarded for posterity. Ultimately, however, the episcopate was unable to halt the persistent squeeze that the guardians of the monarchical state placed on its model of episcopal power.

The episcopate's struggle was made all the more difficult because of the pervasive grasp of political gallicanism on many of the guardians of the realm's public interests. Over the course of the seventeenth century, its central tenets gained increasing credence among jurists, royal officials and parlementaires alike, 
and were articulated and publicised with consummate skill by writers like Pierre Dupuy. ${ }^{2}$ Political gallicanism coloured their attitude towards the pope, for it assumed that he held no power of jurisdiction in France and that the king answered to no one but God for his behaviour. However, it also informed their actions towards the French church and its leading hierarchical representatives, the bishops. Imbued with a dogma that presumed that the gallican church should be independent of Rome, political gallicans also unrelentingly sought to place it firmly under the control of the temporal realm. Although the seventeenth-century episcopate did contain some political gallicans like the politique archbishop of Reims, Charles-Maurice Le Tellier, this form of gallicanism was of a rather different hue from that of the many bishops who can be identified as episcopal gallicans. They found it impossible to stomach a notion of secular supremacy that dared to dictate to the consecrated episcopal leaders of God's church by controlling or appropriating their jurisdictional powers.

The bishops' situation was also particularly complicated by the fact that the episcopate was a child of the crown, with intimate ties to its secular family. Since 1516, the reigning monarch had chosen his bishops, subject to papal approval. In the seventeenth century, that prerogative frequently meant that many bishops owed loyalty not only to their monarch, but also to those who had guided them towards royal approval and into their seats. Joseph Bergin has carefully traced the labyrinth of paths to the episcopate, clearly identifying the many bishops who owed their episcopal careers to Richelieu, Mazarin and members of the royal family. Personal favour, clientage and royal service could all bring their rewards: among those who found this out were the diplomats Arnauld and Malier du Houssay, the former intendant Bosquet, the agent general La Barde and Richelieu's clients, Jaubas de Barrault and Etampes. ${ }^{3}$ Bergin has also demonstrated that, through the century, the overwhelming majority of prelates emerged from the nobility, with some owing their positions to ambitious relatives who acted as their patrons or who had climbed the social ladder far enough to attract royal notice. Without his brother's ascent to political dominance in Louis XIII's reign, Alphonse Richelieu might never have become the bishop of Aix and archbishop of Lyon, and Nicolas Colbert certainly owed his terms in Luçon and Auxerre to the rising fortunes of his envied family under Mazarin and Louis XIV. ${ }^{4}$

Once seated, many bishops retained full-blown or residual loyalties to their patrons, a thorn in the side of episcopal reformers who, while recognising that nobles were the natural leaders of society, knew that bishops could be pressurised and persuaded into using their office to benefit their relatives and friends..$^{5}$ Equally, political obligations and the prospect of further favour or reward could influence episcopal actions. The court prelate and Mazarin aide Pierre de Marca, for example, was initially instrumental in the campaign to 
produce the 1657 articles in Assembly but, eventually, made a complete aboutturn to seek their burial in accordance with the government's wishes. Even when a bishop was not an intimate créature of a leading political figure, he still had to represent the crown locally, keep the government informed on regional affairs and cultivate political and social stability. In the extraordinary circumstances of war and rebellion, bishops were expected to act as peace brokers on the crown's behalf: ${ }^{6}$ during the Fronde, Henri de Béthune, archbishop of Bordeaux, successfully defused a potentially explosive political and social crisis in his province by mediating between the governor and parlement of Guyenne. ${ }^{7}$ More routinely, bishops were instrumental in controlling popular festivities, eradicating superstitions and limiting feast days, activities that were perfectly attuned to the government's desire to maintain social order. ${ }^{8}$

Bishops, therefore, had a foot in each camp, ecclesiastical and temporal. This raised fundamental questions about their identity and role. To whom did they owe their loyalty? How deeply should they become involved in secular affairs? What should inform their behaviour when episcopal and secular ambitions appeared to clash? Of course, other bishops had encountered these dilemmas through the centuries, but the pressures had perhaps never been quite so intense. Seventeenth-century French bishops functioned in a regime that demanded much of its nominees and tempted them with opportunities to amass fortunes and reputations. Their quandary was heightened by the prevailing climate of reform, which tended to spotlight starkly the dangers of selfishness and worldliness that menaced any prelate who delved too deeply into secular affairs. Yet it simultaneously suggested that bishops defend themselves and the church against those who would injure their dignity. Quite often those threats came from within the governing hierarchy itself, but just as the episcopate and the popes clashed over governmental boundaries, so too the bishops and the crown's representatives found themselves at odds over contested realms of jurisdiction at both local and national levels. If bishops were to protect their authority against an incursive state, then it was surely necessary for them to pay attention to politics, to become involved in litigation or to visit the court.

Despite, or sometimes because of, the episcopate's customarily intimate relationship with the government, the Assembly of Clergy frequently played host to intense power struggles between the guardians of the church and the state. It is no longer fashionable for historians to write of the absolute monarchy of Louis XIV, for the image of absolutism hid a governmental system that worked on a shifting pattern of alliances, patronage and negotiation. ${ }^{9}$ Yet although monolithic absolutism has been revealed as a flimsy construction, there is no doubt that governmental power grew steadily over the course of the seventeenth century. ${ }^{10}$ Like every other section of the population, the episcopate 
experienced the effects of the crown's assertiveness. However, just as local notables and even peasants could find ways to challenge royal power, so too the bishops could use their assets to negotiate their own objectives. Quite often, the Assembly played host to collusive transactions, for the bishops and the crown sometimes shared the same goals, though perhaps for different reasons. As the holders of the French church's purse strings, the bishops could occasionally use its assets to bargain for advantages in jurisdiction. That produced a positive result in 1695 when the bishops managed to squeeze official confirmation of their authority over the lower clergy from a crown desperate for ready cash to fuel its war. Yet this was just one episode in a constant financial wrangle between the church and the crown, in which the crown ultimately held the upper hand. From 1665 onwards, the don gratuit became a customary donation rather than an extraordinary subsidy, despite the Assembly's protest that it was a voluntary contribution rather than a fixed obligation. The clergy were now wrong footed, for the precedent was set: it was not a question of whether they would give financial aid but of how much they would have to offer. That significantly reduced their ability to use the contribution as a bargaining tactic. ${ }^{11}$

The bishops were not always able to bargain successfully with the crown, and it was certainly not an easy task to police every effort by the state's representatives to usurp their jurisdictional power. To protect ecclesiastical rights against temporal encroachment, they had to concern themselves with two distinct areas of vulnerability: their own prerogatives and those of the church as a whole. Of course, for the episcopate, one could never truly separate the two, for attempts to limit its power ultimately damaged the entire church. It was its duty to defend the church from secular intrusions which would dishonour its roles of leadership and protection and leave bishops as the simple lackeys of the state. Although the bishops generally concentrated exclusively on their jurisdictional rights in their quarrels with other clergy, they understood their struggles with the monarchy and its representatives in a far more expansive way. That did not remain an implicit or unconscious assumption, but was articulated at every opportunity: every attack on the church was an assault on the bishops who governed it.

For this reason, the episcopate needed to maintain a vigilant eye on government officials, and to react quickly and vigorously when they attempted to assume or control episcopal powers. Significantly, the bishops never directed their anger towards the king; rather, they preferred to blame his ambitious and deceitful servants and to lambaste them for their criminal attempts to undermine episcopal and ecclesiastical authority. Alternatively, they attacked the state in abstract, carefully avoiding any suggestion that they might harbour treasonous sentiments. This was an attitude befitting an episcopate that played a major role in the perpetuation of the theory of divine right; in fact, one of its 
most famous members, Bishop Bossuet, produced the ultimate vindication of the king's absolute and God-given right to rule in his famous treatise, Politique tirée des propres paroles de l'Écriture sainte..$^{12}$ It also fitted perfectly with the first of the 1682 Articles which confirmed that the pope held no jurisdiction over the king's temporality. ${ }^{13}$ Yet the episcopate had certainly travelled a long way since its energetic campaigns, several decades earlier, to reject this very doctrine. ${ }^{14}$ Those particular episodes, in 1614 and 1625, were complicated by the fact that the bishops were also defending the church's exclusive prerogative to judge matters of faith. When the third estate introduced an article denying the pope's temporal power to the 1614 Estates General, the episcopal deputies reacted swiftly and furiously to denounce this lay attempt to encroach on the territory of the first estate. ${ }^{15} \mathrm{~A}$ decade later, one of their colleagues, Leonor d'Etampes, inadvertently sparked another row when he was chosen by the Assembly to respond to anonymous pamphlets which defended the pope's right to depose rulers who were heretical or persecuted the church. Moving to the other extreme, Etampes drafted a censure that endorsed the independence of secular rulers and advocated absolute obedience to them at all times. ${ }^{16}$ Horrified that he had exceeded his remit, his fellow bishops then desperately sought to backtrack by convening at Saint-Genevieve to issue a disavowal of the declaration. They did so despite the disapproval of the Paris parlement which fought desperately to prevent them from either deliberating on or judging the issue. ${ }^{17}$ Behind the bishops' actions in these incidents lay a emphatic declaration of the church's rights: no secular body could prevent the church from passing judgement on spiritual matters, and no member of the laity could attempt to judge Catholic doctrines. More particularly, this was an assertion of their rights, based on the notion of episcopal leadership. As bishops, they were obligated to ensure that the church's unique role as the definer of faith was protected. In neither case, however, did the bishops expressly raise the question of their specific role in judging matters of faith. It would not be until the 1650s, in the Formulary crisis, that they would need publicly and explicitly to address that problem.

These were arguments that turned on the capacity or otherwise of secular institutions and individuals to become involved in spiritual affairs. In both, the bishops were entirely successful in ensuring that neither the opinions of the gallican third estate nor those of the parlement were imposed as official dogmas on the French church. However, with the exception of one further occasion, in 1665 , the episcopate did not need to worry that its spiritual jurisdiction would be usurped. ${ }^{18}$ Instead, it fought to defend its disciplinary jurisdiction. Still, the same fundamental principle was at stake in both kinds of dispute: the laity were not permitted to involve themselves in affairs of religion. It was the leaders of the church who should deal with all ecclesiastical causes, of both faith and discipline, given their special nature. In these struggles, the episcopate's resistance 
to what it saw as temporal threats to its jurisdiction had much in common with its opposition to the supposed privileges of regulars and to the curés' Richerism. Like the lower clergy, the state had tangible gains to make if it could manipulate the episcopate's jurisdiction. The French church was composed of thousands of clergy, who were largely immune from secular jurisdiction. It administered its own system of discipline according to canon law and under the oversight of diocesan bishops. In short, this virtually autonomous institution was a lucrative pool of plunder for those crown officials who cast covetous eyes over its jurisdiction, its properties and its personnel. In doing so, they threatened the power of its governors, the bishops.

Of course, for these officials it was firmly within the government's remit to intervene in the church's spiritual and disciplinary affairs. That principle became abundantly clear when the crown decided to drag the new archbishop of Paris, Cardinal de Retz, into its courts in early 1654. His fresh status as archbishop swung the episcopate's attention to his cause, spurring it to defy this civil effort to judge a bishop. It did so for two reasons. In the first place, the clergy were traditionally exempt from civil trials: that principle would certainly apply to a bishop of the church. Second, the Council of Sardica had elaborated detailed procedures for the trial and judgement of bishops. No secular authority could presume to ignore that episcopal right and to judge or punish any bishop suspected of misdoing. Revealing his usual adept taste for propaganda, Retz successfully appealed to the episcopate's sense of unity and communion in his calls for its support, loudly complaining that the crown treated its brother as 'a bandit or captain of thieves'. ${ }^{19}$ Indeed, this was a common tactic used by bishops to inspire their brethren to resist the encroachments of the temporal power, just as they sought to cultivate a common sense of purpose and identity in their disputes with the popes and lower clergy. Godeau complained heartily about secular infringements, and pointed out that 'the bishops making only one bishop, the injury of one is the injury of all, or rather of the whole church. ${ }^{20}$ Faced with the kind of concerted episcopal defiance that Godeau sought to inspire, the crown felt forced to request that Retz be tried by papal commissioners, and officially recognised that it had overstepped the mark in attempting to pursue his case in a secular court. ${ }^{21}$ That was a significant retraction and a pleasing victory for the episcopate.

The convictions of political gallicans were far too extreme for even the most gallican of bishops. While they happily endorsed the view that the pope could not intervene in the government of the French church, they were equally convinced that it was the episcopate who should manage its affairs, and that the temporal government had no business initiating interventions into its domain. These men were episcopal gallicans first and foremost, and although that category incorporated elements of political gallicanism it did not stop them from 
regularly clashing with the political gallicans who represented the secular government. They were even, on occasion, perfectly willing to ally themselves with the papacy to deflect incursions on their territory: both Rome and the bishops thoroughly disagreed with the crown's plan to try Retz. Most of them also took issue with the complete veto by political gallicans on the decrees of the Council of Trent, for they did not see why these would inevitably extend the tentacles of papal power in France or damage episcopal jurisdiction. In contrast, the crown never showed itself to be more than superficially enthusiastic towards Trent's formal publication because, on several counts, the Council's decrees contradicted French laws and gallican liberties. The ever vigilant and intensely gallican Paris parlement hotly opposed all efforts to promulgate the decrees officially. ${ }^{22}$ Yet, besides publishing the decrees in their synods and adopting the Tridentine programme in their dioceses, the bishops repeatedly requested that the Council's decrees be given legal status in France in order to ensure its implementation. After the clerical Assembly of Clergy had accepted them in 1615, Cardinal de La Rochefoucauld repeated its call for legal confirmation in 1626. Among those who had pleaded for publication before La Rochefoucauld were Cardinal Du Perron, Jérome de Villars, André Frémiot, Camus and Harlay. ${ }^{23}$ By 1660, however, the bishop of Autun's was an isolated voice when he requested that the decrees be published officially. ${ }^{24}$ As the century progressed, the episcopate grew resigned to the fact that legal force would not be granted to the decrees, and its appeals for this halted.

Despite their tugs of war with successive popes, the bishops' sustained support for the publication of Trent's programme highlights their sense of membership within the universal Catholic church and their desire that the French church should align itself with general Catholic discipline and doctrines as far as possible. On occasion, however, the temptation to use Trent's ambiguous status in France to slip out of tricky situations proved irresistible. Frequently, the bishops were happy to rely on its decrees to bolster their authority, as when declaring their disciplinary power over regulars and curés. Yet it was not always convenient to do so, for Trent did not invariably serve their purpose: the bishops simply ignored the Tridentine decree that confirmed the pope's right to judge episcopal causes, and concentrated on the decrees of the ancient Council of Sardica instead. Certainly they recognised that this was not in itself a watertight defence. At least two of them felt obliged to brace the decrees of Sardica by pointing out that the Council of Trent had not been officially adopted in France. Both Montchal and Gondrin must have known that the Assembly of 1615 had received the decrees on behalf of the French church, but they carefully chose to ignore that fact and to play on its exclusion from the law of the land in order to present a winning argument for the episcopal camp. 
At the same time, the episcopate's persistent calls for Trent's publication reflect its view that the church and the state, the twin pillars of society, were joined in a mutually reinforcing relationship that ensured order in society. This was an entirely conventional view for seventeenth-century churchmen to take. The episcopate simultaneously drew on the notion that both church and state had their own spheres of jurisdiction. In principle, therefore, any infringement on the ecclesiastical realm by the secular was a direct attack on, or 'a sacrilegious usurpation' of, the rights of the church. ${ }^{25}$ In practice, however, this distinction was extremely difficult for the bishops to achieve, not simply because the secular authorities seemed to violate it at every opportunity, but also because the episcopate itself tended to blur the boundaries whenever it suited its ends. That happened on numerous occasions. Bishops often called on the secular arm to ensure that their regulations were enforced. ${ }^{26}$ The most obvious instance of the church's reliance on the state occurred in 1664, when the king issued an edict obliging all clergy to conform to the anti-Jansenist Formulary. ${ }^{27}$ The bishops could and did justify this kind of collusion by claiming that the state was dutybound to support them whenever it could, for their work served greater purposes, the glory of God's church and the salvation of souls. Ultimately, therefore, despite the importance of the temporal order, it was inferior to the church, the 'column and firmament of truth'. ${ }^{28}$ This was much less radical than it might seem, for the episcopate did not intend to overthrow the state; rather, it sought to use the state's armoury to protect its position. It was acceptable, therefore, for the crown's officials to intervene in the bishops' affairs when they specifically requested their assistance. Otherwise, these should be allowed to make full and exclusive use of their power of government. It was, however, a difficult balance to achieve: for in allowing secular intervention in their affairs on some occasions the bishops simply whetted the appetites of officials.

This was a dilemma that was most vividly illustrated when the bishops occasionally resorted to appels comme d'abus, one of the favourite devices used by parlementaires to subvert episcopal authority. ${ }^{29}$ Appels were enticing traps for bishops: they detested the fact that these enabled the secular powers to steal their jurisdiction, but they offered short-term gains, while making it extremely difficult for the bishops to condemn anyone else who used them. Of course, each diocese possessed its own court to deal with ecclesiastical causes but, to the exasperation of their prelates, individual ecclesiastics pronounced guilty in these frequently appealed to the sovereign parliamentary courts in order to have the judgements against them overturned; it was the 'fashionable' appels comme d'abus that enabled them to do so. In theory, these appels were limited to cases in which the ecclesiastical judge 'notoriously' exceeded his power or when there was a 'manifest enterprise' against the liberties of the gallican church..$^{30}$ In practice, the sovereign courts frequently heard all kinds of ecclesiastical cases, usually 
claiming that these potentially related to the police of the realm and hence came within their jurisdictional remit.

This particularly bothered bishops when they attempted to implement Tridentine innovations in their dioceses. Time and again, they complained that local authorities obstructed their activities and championed clergy who rebelled against their discipline on the basis of time-honoured customs. Most frequently, recalcitrant clergy appealed to their local parlements in order to have troublesome episcopal ordinances overturned. So, for example, the religious orders quite often appealed to their provincial parlements in disputes concerning the degree of episcopal jurisdiction over their members, as happened in Henri de Sourdis's dispute with the regular clergy of Bordeaux during the 1640s. Even though Sourdis had issued an interdict against the regulars, the Bordeaux parlement willingly granted them leave to continue their pastoral care after they brought an appel against the archbishop's judgement. ${ }^{31}$ The secular courts did not limit themselves to cases involving the regular orders: Harlay's dispute with the curés of Rouen during the late 1620s involved the provincial parlement when, reacting to complaints by members of the parish clergy, it issued an arrêt forbidding the archbishop's officials from proceeding against the curés. ${ }^{32}$ François Hallier recalled this particular episode over twenty years later in a work commissioned by the Assembly to highlight its grievances against secular officials. Declaring that the problem of usurpation of ecclesiastical justice had worsened drastically within the previous half-century, Hallier incorporated Harlay's experience as an illuminating, if infuriating, example of the manner in which the church was persistently stripped of its 'honour and authority [and] discipline'. . $^{33}$

An exasperated episcopate repeatedly declared these kinds of interventions by the secular courts to be absolutely unacceptable, and insisted that ecclesiastical cases should not be resolved within the framework of secular justice. Successive bishops judged appels to be the prime manifestation of a general pattern, whereby the servants of the crown persistently subverted episcopal authority. By 1635, the episcopate's exasperation had reached such heights that it seized its chance to denounce this sabotage in the Assembly's cahier, and it repeated its protests in 1645,1655 and $1675 .{ }^{34}$ The cahier began with a stream of embittered objections to civil justice which drew attention not only to the autonomy of the church in religious affairs but, specifically, to the power of embattled bishops in their dioceses and over clergy: municipal officials chose preachers and refused those delegated by local bishops; they dictated the times for religious services and claimed precedence in local assemblies. Some of these complaints tended to revolve around relatively minor issues of honour, though in seventeenth-century France, precedence in processions and assemblies was an important indication of rank and the episcopate obviously felt that its special status was not always being recognised. ${ }^{35}$ These common snubs together formed 
a continuing affront to an episcopate that prided itself on the privileges of its office. To defeat the various 'empiètements' on their territory, many bishops like François and Henri de Sourdis produced detailed ordinances prescribing the limits of civil jurisdiction and repeatedly forbidding the secular authorities to regulate feasts and preaching. ${ }^{36}$ But it was the appels comme d'abus which provoked their greatest displeasure: '[The judges] suspend the execution of ordinances . . ., overturn the ecclesiastical judgements, they take cognisance of all the personal causes of ecclesiastics ... which are very great enterprises against the jurisdiction of the Church. ${ }^{37}$

Yet the discontentment revealed in the cahier was not simply a function of the fact that the secular authorities persisted in their efforts to squeeze episcopal jurisdiction. They simultaneously damaged episcopal dignity and status within the church and society. Early in the century, the bishop of Aire pointed this out in a remonstrance to the king, and it became a familiar refrain in the episcopate's assessments of its relationship with the temporal realm. Prelates were the judges, fathers and pastors of the faithful, argued Philippe Cospeau; to force them to plead before and to obey lay judges was a perversion of the true religious order because it placed the pastor beneath the sheep..$^{38}$ Equally, bishops were urged to challenge these insults to their authority and status, and to do so not simply on their own behalf, but for the benefit of the whole church. In 1660, Bishop Mathieu Bourlon presented a remonstrance to the Assembly, partly based on his own experiences in Soissons. He began by describing the offence to his authority when the civil courts interfered in ecclesiastical causes, then broadened his commentary to draw attention to the wellbeing of the entire church. Bourlon presented the episcopate as the courageous defender of the church, with responsibility for protecting its powers and rights against those aggressive jurisdictional rivals who violated ecclesiastical 'decrees and liberties' ${ }^{39}$ His rallying words did not fall on deaf ears, for other bishops certainly conceived their role in these fighting terms. Alain de Solminihac vigorously resisted the attempt by the parlement of Toulouse to release two ecclesiastics whom he had imprisoned for misconduct. He did so, he explained in 1650, because he knew that, as a bishop, he was obliged to defend the church's jurisdiction against illegitimate 'enterprises': 'Were it necessary to risk one's life for this, I would willingly do so in order to prove my case and conserve the jurisdiction of the church in its entirety. ${ }^{40}$ This willingness to oppose civil 'empiètements' on behalf of the church was, Godeau agreed, one of the most necessary qualities of a 'true Bishop'. ${ }^{41}$

A 'true bishop' was an apostle of Christ, and it was upon this ancient image that the bishops grounded their opposition to temporal officials. God granted their jurisdictional power so that they could 'establish the spiritual reign of Jesus Christ in the world'. Following the examples of the first Apostles, they 
should defend that gift so that it was neither abused nor eroded. Like Saint Paul, they were also bound to defend the sheep over whom they had been set. ${ }^{42}$ Underpinning that inspiring portrait was the assumption that a bishop's involvement in disputes should never be animated or in any way influenced by selfinterest or personal ambition; he should become involved in 'affairs of the world' solely for the 'service of Jesus Christ' ${ }^{43}$ Solminihac articulated that rule when he opposed the local parlement's effort to regulate the rules of his seminary in Cahors: 'I would willingly have dropped all the lawsuits for the aversion that I have for them, but I was forced by the vow that I took to conserve the rights of my church and by my obligation to watch over the conduct of souls with which I was charged.'

By distinguishing ecclesiastical interests from personal ambitions and profane affairs, bishops like Solminihac were able to respond to that particular episcopal worry: how to avoid being ruled by secular interests. It was sometimes necessary to become involved in temporal affairs, admitted the bishop of Cahors, when they threatened episcopal jurisdiction and ecclesiastical health, but the harvesting of his diocese's 'fruit' ought always to be a bishop's priority. Only if an affair directly bore on the spiritual health of the church and its faithful should he enter the minefield of secular politics and legalities. ${ }^{45}$ Of course, prelates were not required to detach themselves completely from the affairs of the world, for even Solminihac knew that this was impossible in seventeenthcentury society. Although Antoine Godeau and Louis Dony d'Attichy agreed that a bishop should display prudent reticence in tolerating opposition, they were careful to add that all prelates should invariably be prepared to defend 'the honour and liberty of the church' ${ }^{46}$ This advice was not difficult to manipulate, for virtually any issue could be deemed to have possible repercussions for the church and its bishops. François de La Rochefoucauld assuaged his conscience by developing this justification of his political activities. The cardinal was particularly sensitive to the accusation that he neglected his religious responsibilities in favour of his services to the crown. He also resented the fact that hard-line political gallicans insisted that bishops had no business meddling in affairs of state, even while they threatened to thrust themselves into the ecclesiastical realm. As a president and ordinary member of the Conseil $d u$ Roi, ${ }^{47}$ La Rochefoucauld knew that their criticism was directed firmly at him, but he found comfort in the example of Saint Augustine, who had assumed secular cares only when it became necessary for the spiritual welfare of his people. He was an advisor and custodian who ensured that the state did not embrace any doctrine or policy which was prejudicial to its subjects' salvation but, like La Rochefoucauld, he never actively sought secular office. ${ }^{48}$ La Rochefoucauld could also have drawn satisfaction from Jean-Pierre Camus's claim that bishops could legitimately act as royal advisors: as spiritual leaders, they were duty-bound to 
advise the faithful, one of whom was the king. ${ }^{49}$ Ultimately, however, La Rochefoucauld's conscience appears to have bettered him. Troubled by the long absences which prevented him from devoting his full attention to the faithful of Senlis, he eventually resigned the see to a hand-picked successor, Nicolas Sanguin, in 1622.

Contemporaries generally acknowledged that La Rochefoucauld was not a politique prelate, but one who had 'strayed into politics for non-political reasons' ${ }^{50}$ Yet although he was at least temporarily convinced of the validity of his defence, it could be manipulated by less scrupulous prelates to rationalise persistent immersion in affairs of state. Both Godeau and Dony were highly critical of bishops who spent all their time in politics or at court, scathingly describing them as base and unworthy of their office and as lacking in 'moral integrity'. Ideally, visits to court should be undertaken only 'for necessities and interests of God and the Church' and to advise the king on matters pertaining to his spiritual health. ${ }^{51}$ Godeau privately blasted the courtly episcopate of Pierre de Marca who, he believed, had been excessively worldly and insufficiently motivated by religious principles in his political activities. To solicit the court for favours was distasteful enough, Godeau observed caustically, but to live one's vocation as a politique was simply inexcusable. In many ways, Marca and other court prelates treated the episcopal office as 'a temporal dignity' to be won and retained by 'intrigue, favour, complaisance and cowardice'. From Godeau's perspective, however, it was 'a spiritual dignity and a continuation of the priesthood of Jesus Christ'. Episcopal activities, whether purely ecclesiastical or partially temporal, should always be motivated and directed by this fact. ${ }^{52}$ This interpretation of episcopal action informed the vocations of many bishops of a dévot stripe, and related closely to the opposition of prelates like Philippe Cospeau to France's anti-Habsburg and anti-papal foreign policy during the 1620s. Obviously, however, its canons stacked into a rather biased and lopsided understanding of the powers enjoyed by church and state, designed to ensure that the civil authority did not claim the right 'to use the church like a domain'. ${ }^{53}$

Despite the episcopate's successive demands that the 1635 cahier be registered and its suggestions implemented, it never managed to persuade the crown to do so. A quarter of a century later, Dony d'Attichy was obliged to lament the secular incursions that bishops still had to endure when he addressed the Assembly of Clergy. All those bishops then in Paris received a personal invitation to hear him applaud the example of Thomas à Beckett, who had not hesitated to advise his king of the abuses committed in his name or to impress upon him the fact that he would one day be forced to render account to God for his administration. Dony urged his fellow bishops to follow the saint's 
example, in '[speaking] efficaciously to the King and [awakening] his scruples by very respectful but very strong remonstrances, oral and written, to the fact that his officers violate with impunity . . . ecclesiastical jurisdiction ... and that it is for his honour and his conscience to prevent them.' Most substantially, he argued that a deteriorating situation could be remedied if the 1635 cahier was verified, the Tridentine decrees legally confirmed and the papacy requested to support the episcopate's struggle.

Dony was also one of several prelates who proposed that regular provincial councils be held to instil ecclesiastical discipline and encourage united episcopal leadership. This was an important proposal, ${ }^{54}$ and it was envisaged as a crucial element of the tough action that bishops should take to defend their jurisdiction: Dony also urged his confreres to refuse to execute lay judgements, to issue canonical penalties against officials who undertook these illegal transgressions, and to exercise strict control of the lower clergy. ${ }^{55}$ Yet he must have suspected that he and his colleagues were fighting an uphill battle. If he did, those misgivings were realised just five years later. In 1665, the parliamentary Chambre des Grands Jours d'Auvergne suddenly decided that it should increase the portion congrue of the lower clergy, and then allowed its commissioners to assume episcopal powers of visitation in the region. ${ }^{56}$ Worse still, at the same time the avocat général, Denis Talon, affirmed in parlement of Paris that 'temporal princes have the right to judge dogmas of faith and all ecclesiastical discipline' ${ }^{57}$

Naturally, the bishops were incensed at these wholesale assaults on their power, and slammed the unprecedented maxims as 'injurious and pernicious to the church' that they governed de droit divin as the Apostles' successors. ${ }^{58}$ Yet their sustained failure unambiguously to demarcate the boundaries of secular and ecclesiastical jurisdiction was at least partially responsible for Talon's emphatic plea. He had been responding to the failure of some clergy, including several bishops, to obey the 1664 royal edict against Jansenism. Members of the episcopate had been perfectly happy to allow the crown to assist the church in eradicating heresy by strong-arming Jansenists into signing a Formulary that was concerned with religious doctrine. Talon was able to inflate the crown's initiative and prominence in this collusion to suggest that the temporal authority possessed, equally with the leaders of the church, the power to judge questions of faith and discipline. After all, he believed that he possessed evidence to illustrate that it had done so in seventeenth-century France. His claim was simply too extreme for the episcopate, however, which considered itself to be the sole authority in morals and faith: 'The church [cannot] exist with several heads.' Even the king was a 'sheep' in spiritual affairs, bound to listen to the bishops, his pastors, to whom 'alone God gave the power to judge dogmas of faith' ${ }^{59}$ Yet the crown proved conspicuously reluctant to offer satisfaction when the bishops demanded that the decision of the Grands Jours decision be overturned and that 
Talon withdraw his assertion. ${ }^{60}$ It agreed to suspend the decisions of the Grands Jours but flatly refused to force a full retraction from the avocat. Finally, the Assembly had to censure his 'schismatic and heretical' plea itself. Learning from Mazarin's attempt to doctor its resolutions in 1657, it also took the precaution of sending copies of the procès-verbal to every bishop in France. ${ }^{6}$

In the light of the crown's steadfast refusal to accommodate the episcopate in 1665, it appears odd, at first glance, that it should agree to issue an edict some years later that seemed to offer the bishops security against secular interventions in their government. One of its stated purposes was to prevent the disorders that conflicts between church and state could produce 'to the detriment of ecclesiastical jurisdiction', and it spoke respectfully of the 'honours' due to the 'first order of our realm' ${ }^{62}$ In fact, the 1695 edict fell far short of the bishops' desires and painted a picture of their power that was partially at odds with their perception of the relationship between the ecclesiastical and temporal authorities. It was a declaration of secular competence over the church that perfected suited the gallican sentiments of the monarchy for, despite the claim that 'We desire that archbishops [and] bishops . . . may be maintained in all the rights . . . and advantages, that they enjoyed or had to enjoy until now' ${ }^{63}$ many of the articles contained stings in their tails. Although they confirmed the bishops' jurisdiction over the lower clergy and ordered parlements and officials to co-operate with and respect their ordinances, they completely failed to eradicate that bane of bishops' administrations, the appel comme d'abus. Indeed, the edict specifically affirmed that parlements could accept these appeals in an impressive range of cases, including those concerning 'divine services, church repairs, purchase of ornaments, the subsistence of parish priests, ... corrections of ecclesiastics' morals, and all other things concerning ecclesiastical discipline' ${ }^{64}$ With that deadly final phrase, the edict completely dismissed the bishops' century-long complaints and, equally emphatically, vindicated the interference of temporal officials in their rule. Finally, article 30 rejected the episcopate's dearly held conviction that it should be the principal arbitrator of doctrinal concerns by safeguarding the secular courts' right to redress 'scandal, and trouble of order and public tranquillity, and the contravention of ordinances, that the publication of [a] doctrine will have been able to cause' ${ }^{65}$

Of course, the episcopate did make some valuable gains from this edict, because its hierarchical authority over the pastoral activities of the lower clergy, regular and secular, was confirmed in secular law. But this was achieved at the price of surrendering some of its ideals to the practicalities of living under the ancien régime. Indeed, while the bishops at times managed to benefit from their privileged access to the Bourbon monarchy, they were obliged, overall, to forgo more than they won. Almost every hard-won victory was simultaneously a compromising defeat. That is nowhere more apparent than in the bishops' 
rather ambivalent response to the government's campaign to plunder the régale. This entire episode encapsulated their experience through the seventeenth century; for while the bishops were able to fight off papal pretensions, they never succeeded in breaking the persistent siege of episcopal and ecclesiastical jurisdiction by the secular realm. Nor did they manage to persuade the crown to accept their view of episcopal power and authority. The monarchy endorsed the episcopal vision when it served its interests. Otherwise, it simply followed its own rules.

Among the customary rights that the crown had formally agreed with the church was its power to collect the revenues of certain vacant dioceses (régale temporelle) and to nominate to benefices within these (régale spirituelle). Between 1673 and 1675, Louis XIV began to extend this privilege to every diocese throughout France. ${ }^{66}$ If the bishops had assumed their normal position, one would have expected a serious campaign of resistance to this wholesale invasion of their ecclesiastical territory. However, for men who were so sensitive to jurisdictional boundaries, they remained remarkably silent about it. Thirty-five of them actually formally approved the extended droit de régale in $1682^{67}$ and the Gallican Articles that followed, the first of which confirmed the king's supreme temporal authority. These Articles were then circulated to all the bishops of France, accompanied by the instruction that they should not tolerate any opinion that contradicted the doctrines in them. ${ }^{68}$

Only two bishops, Pavillon and Caulet, resisted the régale's extension, on the basis that the Council of Lyons (1274) had forbidden bishops to permit it, on pain of excommunication. ${ }^{69}$ With both displaying the stiff qualities that had enabled them to weather the Formulary dispute, they maintained their opposition through the 1670s and until their deaths towards the end of the decade. ${ }^{70}$ Each refused to take the oath of loyalty admitting the king's right to the régale in Alet and Pamiers, and, in 1675, declared that those who gained a benefice through it would be excommunicated. Under mounting royal pressure to submit, they then appealed to Rome, allying with Innocent XI, who issued two briefs in 1678 and one in 1680 which praised their steadfast resistance while condemning the crown's violations of the ecclesiastical domain. ${ }^{71}$

It has often been assumed that the ambitions of Louis XIV and his gallican ministers were the driving forces behind the publication of the Articles of 1682, but the crown was often far more conciliatory towards Rome than were its bishops during this episode. ${ }^{72}$ It certainly conceived the Assembly of 1682 to be a means of threatening the papacy into compromising its opposition to Louis's extension of the régale but it did not, as nineteenth-century ultramontane historians liked to think, need to bully the 'fatally weak' episcopal delegates into producing the four articles. ${ }^{73}$ Indeed, the episcopate is still occasionally characterised simplistically as the malleable instrument of the monarchy, but this is a narrow 
evaluation of its position which does not set the declaration within its full historical context and which tends to concentrate on its first article only. ${ }^{74}$ The bishops were certainly under some crown pressure to produce a remedy for the quarrel over the régale, and some proved uncomfortable with the tenor of article 1 . Yet to characterise them as spineless or cowardly fails to take account of the fact that three of the articles offered the episcopate particular benefits which seemed, if not to outweigh the disadvantages of article 1, to compensate for them. The bishops were quite prepared to defy successive popes in order to preserve these. Innocent XI and Alexander VIII made it perfectly plain that they frowned upon their behaviour by issuing strong declarations nullifying their approval of the crown's extension of the régale, ${ }^{75}$ and by refusing to accept the nominations of any of the deputies of 1682 to French bishoprics until $1693 .{ }^{76}$ Even so, the bishops flatly refused to retract their doctrines: when they eventually sent a conciliatory letter to Innocent XII in 1693, it deliberately apologised for the tone, rather than the content, of the articles. ${ }^{77}$

The bishops reacted in two distinct ways to the régale. The overwhelming majority raised little or no objection to its extension. One of Caulet's close associates, Étienne Le Camus of Grenoble, advised him to end his resistance on the basis that Caulet could not hope to prevent the crown's extension of the régale and should simply tolerate the inevitable, rather than risk a rift between the church and the monarchy. ${ }^{78}$ Other bishops agreed with Le Camus even if they inwardly found Louis's behaviour rather distasteful; when they explained their actions to the pope in 1682, they too suggested that it was necessary to compromise with the crown over the régale in order for peace to prevail and for the church to retain its otherwise privileged position in the realm. ${ }^{79}$ Le Camus was certainly discomfited by the crown's action and with the intellectual gymnastics that enabled him to accept it. Like other bishops, he resolved his disquiet by classifying the régale as a temporal, rather than a doctrinal or spiritual, matter and so unworthy of diehard opposition: 'The régale does not touch in any manner the rule of faith, or that of morals, which cannot be changed, or reformed . . . it is an affair of Discipline, . . . and can suffer this salutary softening. ${ }^{80}$ Yet Le Camus actually believed that the crown had illegitimately helped itself to a prize that was not in its power to award, and he privately expressed that worry while outwardly bowing to royal authority: 'I was never able to convince myself that the king had a universal right to the Régale attached to his crown and on all the bishoprics of his realm. ${ }^{81} \mathrm{He}$ had good reason for his discomfiture. One might expect a prelate like the former nuncio, Jerome de Grimaldi to object to the régale's extension, ${ }^{82}$ but even Charles-Maurice Le Tellier, the gallican archbishop of Reims, admitted that 'the régale . . . is a spiritual matter' and that any alterations to its current status should be made by the church. ${ }^{83}$ Yet that did not prevent him from attempting to bully Caulet, one of his provincial bishops, into submitting to the king. ${ }^{84}$ 
On the one hand, the régale could superficially be painted as a temporal affair that did not directly impinge on the episcopate's spiritual and disciplinary jurisdiction. Of course, if this argument was to justify its extension, the bishops also had, a priori, to accept the claim that the king was 'not subject to any ecclesiastical power in temporal matters' ${ }^{85}$ However, in reality, the régale was not simply a temporal matter, as Le Camus and Le Tellier knew, because the royal right to this resource had initially been freely presented by a general council of the church and from spiritual assets (benefices) that were naturally under the jurisdiction and protection of its prelates.$^{86}$ The bishops' position remained difficult to reconcile with the fact that they generally presented themselves as the watchful guardians of ecclesiastical prerogatives, were usually very quick to attack any threat to them and demonstrated unity of purpose and a strong sense of self-identity in doing so. Yet in this case the crown blatantly disobeyed a conciliar decree in order to extend its power over the church, and almost every French bishop, with 'wise condescension', simply accepted its behaviour. ${ }^{87}$ Only Pavillon and Caulet refused to do so because 'My character and several canons ... call me to conserve the rights and immunities ... that God has committed to my cares'; only they, in effect, acted in accordance with the bishops' century-long explanations of episcopal responsibility and jurisdiction: 'Bishops are the depositories of these rights . . . They must therefore employ the authority that they have received from Jesus Christ, to oppose the enterprises of secular persons, although sovereigns, on the rights of the Church. ${ }^{88}$

What does this anomaly in the episcopate's behaviour reveal about its relationship with the crown? Le Camus's remarks exhibit the general realisation within the episcopate that royal power was an increasingly formidable force to oppose and one that should be defied only for the gravest of reasons: 'I will give my goods and my life to content the king our master . . . when it will be a question of giving him marks of my obedience and my inviolable attachment to his person. ${ }^{89}$ Rather than indicating a shift in the episcopate's ideological position, however, this amply demonstrates the extent to which the crown had succeeded in enhancing its authority over the decades. Like the bishop of Grenoble, Le Tellier certainly realised that it would be 'imprudent' to oppose Louis's extension of the régale, and gradually moved to support the king's action on the basis that he would never subject 'his right to any judge, and is resolved to support his declaration and to employ his authority to enforce it' ${ }^{90}$ Correspondingly, 'besides the pleasure that I will have of profiting . . . by giving His Majesty a mark of my attachment and recognition, I find there the consolation of seeing that His Majesty will recognise . . that our maxims . . . are the rampart of the monarchy. ${ }^{91}$ A mix of sycophantic ambition and a desire to avoid incurring royal wrath were powerful incentives to indulge the monarch's behaviour. 
Yet, as Caulet warned, every time the secular power managed to exert its power in ecclesiastical territory, the dam separating church and state was weakened ever further. ${ }^{92}$ He and Pavillon thought in absolute terms of total and consistent resistance to these creeping encroachments; other later seventeenthcentury bishops thought realistically in terms of compromise. Certainly they all realised that the crown made a very formidable enemy, but neither Pavillon nor Caulet could permit himself to shirk his episcopal obligations and to give in to secular pressure. Perhaps Robin Briggs's conclusion that the pattern of episcopal appointments became far more routine and conventional in the 1670s has some significance here. Bishops educated in the Parisian seminaries and faculty of theology, and chosen partly on the basis of their likelihood to conform to the crown's will, would find it increasingly difficult to oppose a government with which they were so closely identified. ${ }^{93}$ Of course, many of their predecessors, like Du Perron or La Rochefoucauld, had been closely bound to the monarchy, but had been noted for independent thought and action. It would appear, therefore, that while the episcopate's ideals remained the same, its members were less willing to defy their government in defending them.

A second, and related, factor influencing the unwillingness of most bishops to displease their government over the régale may have been the cooling of the reform climate within the episcopate by the final quarter of the seventeenth century. It rose to its highest point in the middle decades, with bishops like La Rochefoucauld, Cospeau, Godeau, Harlay, Pavillon and Solminihac demonstrably willing to criticise the government and to refuse to obey its wishes when they felt it necessary for spiritual health. That attitude fitted neatly into the notion of the episcopal apostolate, and was characterised by willingness to actualise ideals of episcopal leadership and integrity. Principles were to be preserved and put into practice; even the threat of royal displeasure was not a sufficient reason to manipulate or abandon them. However, the suggestion that the final generation of prelates under Louis XIV's reign was less affected by this ideal should not be pushed too far, for many of them were not simply submissive yesmen who consistently abandoned their beliefs to avoid royal opprobrium. In the early eighteenth century, the crisis over Unigenitus would demonstrate that they could still put up a spirited resistance on issues that they considered to flout fundamental principles. When the crown sought a straightforward acceptance of the anti-Jansenist papal bull, the special assembly of prelates refused to do so and instead embarked on a painstaking evaluation of its doctrinal provisions in their role as judges of faith in a council representative of all French bishops. ${ }^{94}$

The bishops gained and lost in the régale wrangle and in the gallican crisis that produced the four articles. In failing to defend its own and the church's prerogatives, the episcopate failed to live up to the ideal that bishops had carefully developed and defended through previous decades and left the door wide 
open to further efforts by the secular authorities to dominate it and the ecclesiastical realm. At the same time, however, its formal confirmation of the régale allowed the episcopate to assert, once more, its right to lead the French church and to shape its future, even when the pope disapproved of its decisions. Equally significantly, the Articles of 1682 allowed the episcopate to stake its claim in general ecclesiastical government by formally confirming its conciliarist doctrine, confining the pope's authority over the universal church and denying papal infallibility. For this reason, the long-serving Gilbert de Choiseul could endorse them. His views had not altered over the decades of his episcopal career, for he had always rejected the doctrine of papal infallibility and supported conciliarism, and in 1682 he was still arguing that councils were superior to the pope in matters of faith, morals and discipline. ${ }^{95}$ Like Bossuet, Choiseul referred to the decrees of Constance to support his claim, ${ }^{96}$ and harked back to the conciliarist views expressed by Cardinal Lorraine over one hundred years before. ${ }^{97}$ With justification, both Bossuet and Choiseul placed themselves firmly within a long tradition of French episcopal gallicanism that had been sharply reinvigorated through the seventeenth century.

Episcopal gallicanism placed bishops at the centre of ecclesiastical life. They were perfectly aware that they could defend this ideal most successfully when they brought their collective weight into play, and they took every opportunity to do so, whether through the official Assembly or through specially convened meetings that published and legislated on their behalf. Only very rarely did any bishops use another device open to them: the provincial council. In the early years of the century, three councils were held, ${ }^{98}$ followed by Sourdis's Council of Bordeaux in 1624. But just three decades into the seventeenth century, the episcopate faltered in its implementation of Trent's decree on councils, for Bordeaux was the final provincial council held in seventeenth-century France. The councils did not halt because bishops were discouraged from holding them; actually, quite the contrary. Dony d'Attichy was just one of many prelates who told his fellows that their most effective defence against secular encroachments was united leadership, implemented through a system of regular provincial councils: 'Nothing being more certain, except that it is the sole source of the decadence of the episcopal order, which has occurred only since they have no longer been held.

Bishops habitually called for provincial councils from the early years of the century. In 1610, the Assembly of Clergy exhorted archbishops to convene provincial councils. ${ }^{100}$ The deputies of the 1614 Estates General proved more ambitious when they called for biennial provincial councils and just a year later, the Assembly reiterated this order, directing that provincial councils take place within the following six months. ${ }^{101} \mathrm{~A}$ decade later, it issued a letter to all 
bishops recommending that provincial councils be held for discipline and spiritual health. ${ }^{102}$ This particular instance of reforming zeal was produced in the enthusiasm surrounding Sourdis's warmly received council, but it too failed to show any practical results. Then, in 1645, the Assembly reiterated its earlier demands, actually troubling to back this up with letters patent encouraging archbishops to convoke councils. ${ }^{103}$ Five years later, that hope seemed about to be fulfilled when Harlay of Rouen began to organise a provincial council for his archdiocese, persevering with his arrangements even when the local parlement issued an arrêt forbidding the council to sit. ${ }^{104}$ Given the resistance of local authorities to any impingement of Tridentine rules on regional customs, it was not unexpected that the parlement should assume this position. The Assembly sternly rebuked it for its unwarranted 'enterprise', and encouraged Harlay to oppose its sabotage 'with vigour and courage'. ${ }^{105}$ A promise of royal support gave Harlay new energy and he continued with his plans until they were thwarted by the political upheaval of the Fronde and, ultimately, by his inopportune death in 1651. His disappointment did not deter bishops from continuing to present provincial councils as the best means of ensuring episcopal authority and dignity and of preserving discipline within the church: François Faure and Daniel de Cosnac both called for provincial councils in the mid-1660s, a move that would, Faure claimed, restore the church to its ancient brilliance. ${ }^{106}$

If French bishops envisaged provincial councils to be among the principal means by which their conception of episcopal leadership could be actualised, why were so few of them held in seventeenth-century France? That intriguing question has never been satisfactorily addressed by historians; beyond making the obvious observation that this aspect of Trent's programme was not really pursued after 1600, they have tended to concentrate on the features of Tridentine organisation which were actually implemented. ${ }^{107}$ Yet, given the theoretical link that bishops constructed between episcopal authority and provincial councils and the prolonged efforts by many of them to implement other Tridentine practices in their dioceses, it is instructive to ask why this particular angle of the Council's programme was not pursued to any significant degree. France was far, of course, from being the only branch of the church without many provincial councils; they were held only sporadically in the Spanish Netherlands and Ireland, for instance. ${ }^{108}$ They could be systematically established, however, as Borromean Milan and the Spanish archdiocese of Tarragona showed. ${ }^{109}$ This is not the place to indulge in general speculation about why provincial councils never grafted themselves onto the post-Tridentine church but, in the context of episcopal ideals, we can certainly make some pertinent observations for one of its major territories. The problem is especially fascinating when it is considered that provincial councils were held in late sixteenth-century France, amid the 
unrest caused by civil war. The evidence does not suggest that seventeenthcentury bishops considered the legislation produced by these to be definitive or sufficient, because they persisted in calling for further councils on the basis that they were essential for fostering unity, fraternity and supportive contact among bishops, as well as for the production of decrees on religious order. ${ }^{110}$

The furore surrounding the 1624 Bordeaux Council offers one reason why bishops did not act on these calls, for the fact that Rome proved so unaccommodating towards Sourdis's reform programme quite probably discouraged other bishops from following his lead. This debacle reflected the jostle for power that preoccupied the ecclesiastical hierarchy in the wake of Trent and, after Sourdis's unfortunate experience, other French bishops were likely to shy clear of such an uncertain means of asserting and exerting their authority. Yet while this disappointment was the most obvious reason for the bishops' failure to translate their stated intentions into actions, it was not the only one. Within their own ranks lay a second contributory factor: episcopal rivalry.

In practice, French bishops displayed a high level of rivalry in their attitude towards their neighbours, even though they successfully shrugged this off when faced with external threats from the papacy, lower clergy or the civil powers. Then they were generally able to present a united front, acting in concert to defend their collective rights. Within their own corps, however, their rivalry occasionally erupted into stormy conflicts, which fractured their unity as each sought to protect his jurisdiction and honour. This kind of clash was all too common through the century and cropped up for all sorts of reasons. Henri de Sponde took umbrage when a neighbouring bishop issued a marriage dispensation for a Huguenot resident in Pamiers, resulting in a spat that was resolved only when the offending prelate formally apologised to the aggrieved Sponde. ${ }^{111}$ Even Alain de Solminihac was not above criticising his neighbours: he complained bitterly to Vincent de Paul that they did not hesitate to poach his priests by offering them tempting benefices. ${ }^{112}$ This kind of friction could also manifest itself in full-blown quarrels between bishops and their archbishops. Once again, Solminihac's episcopate provides a vivid example of how jealously bishops guarded their jurisdictional territory: when Archbishop Hardivilliers reversed a suspension that Solminihac had issued on a curé, the bishop reacted angrily, protesting that this was a completely illegitimate slight on his authority. ${ }^{13}$ Some years before, Antoine de La Rochefoucauld of Angoulême had been equally unhappy with François de Sourdis when he modified a monitoire that the bishop had issued to unearth evidence against a murderer. Like Solminihac, La Rochefoucauld claimed that since his action had been entirely in harmony with canon law, the archbishop had no business interfering in his diocese. ${ }^{114}$ In both incidents, the archbishops were obliged to admit defeat, and the bishops could be satisfied that their jurisdictional powers and reputations remained intact. ${ }^{115}$ 
Yet these very public clashes illustrate the prevalence of diocesan territorialism or exclusivism within the episcopate; sentiments of corporate solidarity did not eradicate rivalry between bishops or their desire to protect their particular jurisdiction from encroachments by their colleagues.

This defensive antagonism spilled into the failure of provincial councils to become a common feature of French episcopal life during the seventeenth century. Cardinal Sourdis succeeded in inserting a clause into the decrees of Bordeaux that enabled him, as archbishop, to interpret its regulations personally until the next provincial council was held. He justified it by claiming that archbishops held the power to judge and interpret the laws made under their presidency. ${ }^{116}$ In fact, the measure was designed to enhance his control within the province, at the expense of its bishops and other clergy. Other archbishops were equally keen to ensure that their authority over bishops was maximised. When the bishops of Comminges, Alet, Pamiers, Conserans and Bazas issued a condemnation of Pirot's Apologie in 1658, the archbishop of the first four sees promptly overturned it and refused to allow its adoption in these dioceses. Archbishop Rebé feared the initiative taken by his suffragans: to him, their meeting and condemnation appeared perilously close to claiming the character and authority of a provincial council, which could legitimately meet and issue decrees only under his impetus and presidency. ${ }^{117}$

In actual fact, when one digs beneath the conscientious calls from members of the episcopate for provincial councils, it becomes apparent that only archbishops appeared to have any genuine enthusiasm for their actual convocation. When Rouen's parlement forbade the holding of a provincial council under Harlay in 1651, the archbishop found himself in the company of only one other prelate when he defiantly presented himself on the opening day of his meeting. ${ }^{118}$ While this may illustrate the gravity with which the bishops regarded the parlement's threat, it also demonstrates that the real desire to initiate regular councils lay with the archbishops, rather than with the diocesan bishops. In practice, therefore, it appears that the episcopate's wish for provincial councils was one which, with the exception of archbishops like Harlay, was largely formal. The vast majority of bishops willingly convoked diocesan synods where they could hope that their jurisdiction and wishes would prevail. But they were unlikely actively to favour provincial councils in which the presiding archprelate would perhaps try to impose his autocratic authority on them.

Stifled by the ambivalent and downright contradictory views within the episcopate and by antagonism from secular authorities, provincial councils never stood much chance of becoming an ordinary part of the ecclesiastical framework: they were simply headaches to organise and implement, and more trouble in practice than they were theoretically worth. Indeed, their absence undoubtedly contributed to the progressive strengthening of the Assembly of 
Clergy, which, in filling the vacuum left by the demise of councils, gradually came to be seen as the representative and authoritative voice of the clergy, and particularly of the episcopate. Still, the persistent calls by the episcopate for provincial councils illustrates that bishops were absolutely aware of the secular realm's ever-increasing tendency to encroach on the affairs of the sacred and, specifically, to appropriate their jurisdiction. But not even their representatives in the Assemblies could halt that distasteful progression. Would provincial councils have eradicated it, as so many bishops alleged? If systematically held, they would have united the bishops at regional level, perhaps enabling them to present a collective front against the attacks of local officials and parlements. However, it is highly unlikely that conciliar legislation, with no confirmation in secular law, would have deterred these determined attempts to dominate episcopal rule. Episcopal gallicanism and political gallicanism differed dramatically in the significance that they ascribed to the jurisdictional role of bishops. This gulf meant that the bishops spent most of the seventeenth century fighting the creeping menace to their authority from the secular realm. Naturally, the sacred and secular powers could often work in tandem and to the bishops' benefit, an advantage that they were not slow to seek and exploit. Yet that collusion worked only when the government wished it, and it meant that, almost invariably, the episcopate was obliged to surrender and to compromise its ideals in order to maintain its uneasy alliance with the temporal authority in France.

Notes

1 The best summary is found in Robin Briggs, Communities of Belief. Cultural and Social Tensions in Early Modern France (Oxford 1995), pp. 181-234. See also Mettam, Power, pp. 243-56.

2 Pierre Dupuy, Traitéz des droits et libertéz de l'église gallicane (n.p. 1639); Pierre Dupuy, Preuves des libertéz de l'église gallicane (n.p. 1639).

3 Bergin, Episcopate, pp. 460-541.

4 Ibid., pp. 322-32, 598, 691.

5 This was a refrain in the writings of reformers. For example: Jean-Pierre Camus, Homelies panegyriques de Sainct Charles Borromee, cardinal du titre de Sainct Praxede, archevesque de Milan (Paris 1623), pp. 116-18; Camus, Hiérarque, pp. 158-9, 189, 225-30, 370-1, 667-8; Godeau, Lettres, p. 286, letter to an unnamed bishop, 23 July 1646; ibid., pp. 318-19, letter to Abbé de Thomassin (n.d.).

6 Bergin, Episcopate, pp. 469-711; Kettering, Patrons, pp. 124-5; Mettam, Power, pp. 247-8.

7 Samuel Martineau took on a similar role in the region: René Toujas, 'Les Démêlés de Samuel Martineau, évêque de Bazas (1646-1667) avec le parlement de Bordeaux,'Actes du 104 Congrès National des Sociétés Savantes, ii (Paris 1981), pp. 51-62.

8 Hoffman, Church, pp. 86-97, 133-4; Luria, Territories, pp. 53-105; Peyrous, Réforme, i, pp. 120-200.

9 Peter Burke, The Fabrication of Louis XIV (New Haven and London 1992); Mettam, Power, pp. 13-44.

10 William Beik, Absolutism and Society in Seventeenth-Century France. State Power and Provincial Aristocracy in Languedoc (Cambridge 1985); Richard Bonney, The Limits of Absolutism in Seventeenth-Century France (Aldershot and Brookfield, Vermont 1995); Briggs, Early Modern France, pp. 73-159; Ragnhild Hatton (ed.), Louis XIV and Absolutism, (London and Basingstoke 1976). 
11 For full discussion of the clergy's financial history see Blet, Clergé . . monarchie, i, pp. 374 96; ibid., ii, pp. 256-87; Blet, Assemblées, pp. 3-33, 84 -90; Claude Michaud, L'église et l'argent sous l'ancien régime. Les receveurs généraux du clergé de France aux xvi--xvii siècles (Paris 1991).

12 Bossuet, Oeuvres complètes, xxiv, pp. 1-259.

13 Du Pin, Histoire, iii, p. 533.

14 These cases are discussed in detail in Pierre Blet, 'L'Article du tiers aux états généraux de 1614', Revue d'Histoire Moderne et Contemporaine, 2 (1955), 81-106; Blet, Clergé . . . monarchie, i, pp. 335-69; Bergin, La Rochefoucauld, pp. 69-73; J. Michael Hayden, France and the Estates General of 1614 (Cambridge 1973), pp. 131-48.

15 Procès-verbaux, ii, p. 21.

16 Leonor d'Etampes, Declaration de messieurs les cardinaux, archevesques, evesques, et autres ecclesiastiques deputez en l'assemblée generale du clerge de France, tenue à Paris. Touchant certains libelles faicts contre le roy et son estat (Paris 1626).

17 AN, G8* 643b, fos 459-60.

18 This is discussed at a later point in this chapter.

19 Jean-François-Paul Gondi de Retz, Oeuvres de Retz, ed. J. Gourdault, R. de Chantelauze and C. Cochin, 11 vols (Paris 1870-1920), vi, p. 28.

20 Godeau, Remonstrance, p. 7: 'Les Evesques ne faisant qu'un Evesque, l'injure de l'un est l'injure de tous, ou plûstost de toute l'Eglise.'

21 See AN, G8* 653, 14 November 1656, for the Assembly's demand that Retz be judged 'following the law and the canonical constitutions, the immunities and privileges of bishops and of the Gallican Church'; Blet, Clergé . . . monarchie, ii, pp. 126, 232-4.

22 Martin, Réforme, pp. 303-43.

23 François de La Rochefoucauld, Raisons pour le désaveu fait par les évesques de ce roiaume d'un livret publié avec ce tiltre Jugement des cardinaux archévesques et autres qui se sont trouvés en l'assemblée générale du clergé de ce roiaume sur quelques libelles diffamatoires (Paris 1626), p. 197; Blet, Clergé ... monarchie, i, pp. 125-33; Martin, Réforme, pp. 377-86.

24 Recueil des actes, vi, col. 165.

25 François Faure, Remonstrance du clergé de France faite au roy (Paris 1666), p. 10; François de La Rochefoucauld, De l'estat ecclésiastique (Lyon 1597), pp. 36-7; La Rochefoucauld, Raisons, p. 286, citing Mark 12:17.

26 Ordonnances, advertissemens, et instructions aux recteurs, et autres ecclesiastiques du diocese de Pamiers (Toulouse 1630), p. 15; Ordonnances ecclesiastiques et statutz synaudaux faictz par monseigneur l'archevesque de Bourges patriarche primat d'Aquitaine, pour le reglement et police du clergé de son diocese (Bourges 1608), 31-2; Ordonnances et constitutions synodales, decrets et réglements donnez au diocèse de Bourdeaux par feu de bonne mémoire monseigneur le cardinal de Sourdis. Reveus, confirmés et augmentés par très-illustre et très-révérend père en Dieu Messire Henri Descoubleau de Sourdis, archévesque de Bourdeaux, et primat d'Aquitaine (Bordeaux 1639), p. 352.

27 Recueil des actes, i, cols 357-60.

28 La Rochefoucauld, Estat, p. 58.

29 Blet, Clergé . . monarchie, ii, p. 292.

30 André-Hercule de Fleury, Oeuvres de l'abbé Fleury (Paris 1884), p. 430.

31 Peyrous, Réforme, i, p. 686. Sourdis was equally incensed when his chapter appealed to the parlement to resolve an internal dispute (in which he was not directly involved): Letter to the Dean and Canons of the Metropolitan Church of Saint André (n.p. 1642).

32 Morestel, Guidon, p. 319. Morestel justified this intervention by arguing that if bishops did not fulfil their ecclesiastical duties correctly, then the parlement was obliged to ensure that curés were protected from new abuses: ibid., unpaginated.

33 François Hallier, De la iurisdiction ecclésiastique au royaume de France (n.p. 1651), pp. 40-1, 81-2.

34 Cahier des remonstrances du clergé de France, presenté au roy par l'assemblée generale, tenue à Paris és années 1635 et 1636. Avec les responses faites par sa majeste sur lesdites remonstrances (n.p. n.d.); Procès-verbaux, iv, p. 263; ibid., v, pp. 180-1. 
35 Bertrand Deschaux, for example, complained that the governor of Bayonne (Gramant) refused to allow him into his episcopal town, thereby symbolically rejecting the newly consecrated bishop's authority and mocking his episcopal 'honour': 'Documents inédits', ed. Philippe Tamizey de Larroque, Revue de Gascogne, 20 (1879), 405, Deschaux to Phélypeaux, 22 July 1611.

36 Ordonnances... Bourdeaux, pp. 350-61.

37 Cahier, pp. 3, 9: 'Ils suspendent l'execution des Ordonnances . . ., renversent les Iugemens Ecclésiastiques, ils prennent connoissance de toutes les causes personnelles des Ecclésiastiques . . qui sont enterprises très-grandes contre la Iurisdiction de l'Église.'

38 Philippe Cospeau, Remonstrance du clergé de France, faicte au roy le 18. iuillet (Paris 1617), p. 20.

39 Bourlon, Remonstrance, pp. 5-9.

40 Solminihac, Lettres, p. 426, Solminihac to Chansarel, 27 November 1650: 'Quand il faudroit y perdre la vie, je l'exposerois volontiers pour en avoir raison et conserver la juridiction de l'Église en son entier.'

41 Godeau, Lettres, p. 317, letter to Thomassin (n.d.).

42 Faure, Remonstrance, p. 9, 31.

43 La Rochefoucauld, Estat, p. 612.

44 The parlement had attempted to regulate the duration of seminary training and the pensions of clerics. Sol, Solminihac, p. 366, Solminihac to Du Ferrier (vicar-general of Albi) (n.d.): 'J'aurais volontiers quitté tous les procès pour l'aversion qui j'y ai, mais j'y suis forcé par le serment que j'ay fait de conserver les droits de mon Église et par mon obligation de veiller sur la conduite des âmes dont je suis chargé.' See also Solminihac, Lettres, p. 553, Solminihac to d'Estrades (bishop of Condom), 20 December 1653.

45 Ibid., p. 553, Solminihac to d'Estrades, 20 December 1653; Recueil des actes, vi, cols 165-7.

46 Godeau, Histoire, iii, p. 706; Godeau, Remonstrance, p. 8.

47 He was appointed president in September 1622 and formally retired in 1624 or 1625: Bergin, La Rochefoucauld, pp. 62-4.

48 La Rochefoucauld, Estat, pp. 331-2.

49 Camus, Homélies des États Généraux (1614-1615), ed. Jean Descrains (Geneva 1970), p. 350.

50 Bergin, La Rochefoucauld, p. 65.

51 Lettres, p. 287, letter to an unnamed bishop, 23 July 1646; Recueil des actes, vi, cols 165-7.

52 Godeau, Lettres, p. 286, letter to an unnamed bishop, 23 July 1646; ibid., p. 319, letter to Thomassin (n.d.).

53 Hallier, Iurisdiction, p. 6.

54 Provincial councils are discussed at a later point in this chapter.

55 Recueil des actes, vi, cols 169-70.

56 The portion congrue was the portion of revenue (or salary) paid by the tithe owner to the resident curé of a parish. Under the ancien régime, it affected approximately one third of all French parish priests: Tackett, Priest, p. 120; Blet, Clergé . . monarchie, ii, p. 326.

57 AN, X1a 8394, 12 December 1664.

58 AN, G8*653, 19 December; Faure, Remonstrance, pp. 8-10.

59 Procès-verbaux, iv, pp. 196-206; Faure, Remonstrance, p. 32.

60 AN, G8*658a, 18 November.

61 AN, G8* 653, 19 December; Blet, Clergé . . monarchie, ii, p. 337.

62 Recueil, ed. Isambert, xx, p. 243.

63 Ibid., p. 255: 'Voulons que les archevêques [et] évêques . . . soient maintenus dans tous les droits . . . et avantages, dont ils ont joui ou dû jouir jusqu'à présent.'

64 Ibid., p. 253: 'service divin, réparations des églises, achats d'ornemens, subsistance des curés . . . corrections des moeurs des personnes ecclésiastiques, et toutes autres choses concernant la discipline ecclésiastique...'

65 Ibid., p. 252: 'la réparation du scandale, et trouble de l'ordre et tranquilité publique, et contravention aux ordonnances, qui la publication [d'un] doctrine aura pu causer'.

66 Blet, Assemblées, pp. 128-31. 
67 Documents relatifs aux rapports du clergé avec la royauté de 1682 à 1705, ed. Léon Mention (Paris 1893), pp. 23-4.

68 AN, G8* 664A, pp. 571-2, 943-50.

69 The dioceses of Languedoc, Guyenne, Provence and Dauphiné were all customarily exempt from the régale: Decrees, ed. Tanner, i, pp. 309-31.

70 Pavillon died in 1677, followed by Caulet three years later: Bergin, Episcopate, pp. 592, 680.

71 Gaillard, Choart, pp. 253-65; Vidal, Caulet, pp. 449-555.

72 Blet, Assemblées, pp. 348-50, 360-2; Martimort, Bossuet, pp. 443-79.

73 Gérin, Recherches, p. 68; Le Maistre, Pape, ii.

74 Orcibal, Louis, p. 7; Mettam, Power, p. 251.

75 In April 1682 and August 1692 respectively. The bishops refused to retract their confirmation: Documents, ed. Mention, pp. 37-43, 48-63; Orcibal, Louis, p. 9.

76 Ludwig von Pastor, History of the Popes, 40 vols (London 1891-1953), xxxii, p. 304.

77 Blet, Assemblées, p. 570.

78 L'Extension de la régale à tous les évêchés de France, ed. Marc Dubruel (Toulouse 1911), pp. 289, Le Camus to Caulet, 21 August 1679.

79 Documents, ed. Mention, pp. 8-9, 12, 20-1.

80 Ibid., pp. 10-11: 'La Régale ne touche en aucune manière la règle de la Foi, ni cele des moeurs, qui ne peut ni changer, ni être réformée . . . c'est une affaire de Discipline, . . . et peut souffrir cet adoucissement salutaire.' See also Extension, ed. Dubruel, p. 28, Le Camus to Caulet, 21 August 1679: 'Il ne s'agit ici que d'un droit sur le temporel de nos églises dont nous devons être moins jaloux incomparablement que s'il s'agissait du spirituel.'

81 Gérin, Recherches, p. 150, Le Camus to Le Tellier, 30 May 1681: 'Je n'ai jamais pu me convaincre que le Roi eût un droit de Régale universelle attaché à sa couronne et sur tous les évêches de son royaume.'

82 Ibid., p. 191, Grimaldi to Michel Le Tellier (chancellor), 12 August 1681.

83 Ibid., p. 42, Memoir (1680).

84 Orcibal, Louis, p. 5.

85 Du Pin, Histoire, iii, p. 533.

86 Gérin, Recherches, p. 159, Le Camus to Michel Le Tellier, 30 May 1681.

87 Documents, ed. Mention, p. 16.

88 Extension, ed. Dubruel, p. 32, Caulet to Le Camus, 19 September 1679: 'Mon caractère et plusieurs canons . . . m’imposent de conserver les droits et les immunités . . que Dieu a commise à mes soin.'; ibid., p. 36, Caulet to Le Camus, 23 July 1680; Gaillard, Choart, pp. 252-3, Pavillon to the Assembly, 8 July 1675: 'Les évêques sont les dépositaires de ces droits ... Ils doivent donc employer l'autorite qu'ils ont reçue de Jésus-Christ, pour s'opposer aux enterprises des personnes séculieres, quoique souveraines, sur les droits de l'Eglise.'

89 Gérin, Recherches, p. 152, Le Camus to Michel Le Tellier, 30 May 1681: 'Je donnerais mes biens et ma vie pour contenter le Roi notre maître . . . quand il s'agira de lui donner des marques de mon obéissance et de mon attachement inviolable à sa personne.'

90 Ibid., p. 125: 'soumettre son droit à aucun juge, et est dans la résolution de soutenir sa déclaration et d'employer son autorité pour la faire valour'.

91 Ibid., pp. 141-2, Le Tellier to Louvois, 29 March 1681: 'Outre le plaisir que j'aurai de profiter . . . pour donner à Sa Majesté une marque de mon attachement et de ma reconnaissance, j'y trouve une consolation, qui est celle de voir que Sa Majesté connaîtra . . que nos maximes . . . sont le rempart de la royauté.'

92 Extension, ed. Dubruel, p. 32, Caulet to Le Camus, 19 September 1679.

93 Briggs, Communities, p. 209.

94 Blet, Louis XIV et le saint siège, pp. 429-80, 577-604; Lucien Ceyssens, L'Unigenitus et sa preparation à Rome (Rome 1984).

95 AN, G8* 664A, p. 759: 'Le concile peut réformer les décrets du Pape.'

96 Ibid., pp. 846-7; Bossuet, Oeuvres oratoires, vi, pp. 86-138. 
97 AN, G8*664A, p. 857.

98 Narbonne (1609), Sens (1612) and Aix (1612): Martin, Réforme, p. 164n.

99 Recueil des actes, vi, col. 163: 'N'y aïant rien de plus certain, sinon que c'est la seule source de la décadence de l'ordre Episcopal, qui n'est déchû que depuis qu'on a cessé d'en tenir.'

100 Procès-verbaux, i, pp. 4, 16.

101 Ibid., pp. 141, 242.

102 Lettre de messieurs les archévesques, touchant la convocation des conciles provinciaux: par l'advis de l'assemblée générale du clergé de France, tenuë à Paris (Paris 1625), pp. 7-9.

103 Blet, Clergé . . monarchie, ii, p. 53.

104 AN, G8*652, 23 November; Blet, Clergé . . monarchie, ii, p. 54.

105 AN, G8* 652, 10 January. This suspicion of provincial councils was not confined to France, but was also evident in Spain, where the secular authorities insisted that royal representatives be present at every meeting and that decrees be approved by the Royal Council. If Harlay's council had gone ahead, it is not inconceivable that the parlement would have insisted on its being represented there: Henry Kamen, The Phoenix and the Flame. Catalonia and the CounterReformation (New Haven and London 1993), pp. 56-62; Wright, 'Ideal', p. 190.

106 Faure, Remonstrance, p. 35.

107 See, for example, the standard works on French reform: Delumeau, Catholicism; Taveneaux, Catholicisme.

108 Alison Forrestal, Catholic Synods in Ireland, 1600-1690 (Dublin 1998), pp. 195-6; Harline and Put, Tale, pp. 110-32.

109 Although Borromeo presided over regular provincial councils in Milan the practice died out under his successors: Prodi, 'Borromée'. Tarragona was the only Spanish province to institute frequent provincial councils. Thirty-six were held between 1565 and 1757, at approximately five-year intervals: Kamen, Phoenix, pp. 77-9.

110 Borromeo had similar aims for his provincial councils: Prodi, 'Borromée', 388.

111 Cinq visites, ed. Contrasty, p. 132; Vidal, Sponde, p. 73.

112 Solminihac, Lettres, p. 298, Solminihac to de Paul, 25 May 1650.

113 Ibid., p. 332, Solminihac to unnamed correspondent, 10 February 1646.

114 Ravenez, Sourdis, pp. 496-7.

115 Richelieu also criticised the tendency of archbishops to appoint candidates to benefices by overruling the decisions of diocesan bishops to reject them: Armand-Jean du Plessis de Richelieu, Testament politique de Richelieu, ed. Françoise Hildesheimer (Paris 1995), p. 132.

116 'Documents', ed. Ducaunnes-Duval, 475. Rome suppressed the rule, arguing that an archbishop's authority did not stretch this far: Gouyon, Introduction, p. 240; Broutin, 'Concile', 408 .

117 Dubruel, 'Hiérarchie' (1919), 337.

118 Bishop Gilles Boutault of Evreux: AN, G8* 652, 16 and 27 January. 